УДК 342.951

DOI: https://doi.org/10.54929/pmtl-issue2-2021-02

\title{
ДЕРЖАВНА СЛУЖБА: ПРОБЛЕМИ АДМІНІСТРАТИВНО-ПРАВОВОГО РЕГУЛЮВАННЯ ІІЇ ПРОХОДЖЕННЯ В ОРГАНАХ СУДОВОЇ ВЛАДИ
}

\author{
CIVIL SERVICE: PROBLEMS OF ADMINISTRATIVE AND LEGAL \\ REGULATION OF ITS PASSING IN THE JUDICIARY
}

\author{
Мінка Т. п. \\ доктор юридичних наук, професор, \\ професор кафедри адміністративного та митного права \\ Університет митної справи та фрінансів, м. Дніпро \\ ORCID: 0000-0001-6012-6973
}

Tatiana Minka

Doctor of Law, Professor, Professor of the Department of Administrative and Customs Law University of Customs and Finance, Dnipro

У статті досліджується проблема адміністративно-правового регулювання проходження державної служби в органах судової влади. Детально проаналізовано адміністративно-правового законодавства про державну службу в органах судової влади. Запропоновано шляхи покращення адміністративно-правового регулювання державної служби в органах судової влади. Автором встановлено, що існуюче законодавство, яке регулює державну службу в органах судової влади не можна говорити про те, що воно вирішує всі питання державної служби. В цій статmі обгрунтовано, що з метою покращення нормативно-правового регулювання державної служби в органах судової влади необхідно покращити підзаконну правотворчість у напрямку уніфікації підзаконних правових актів, узгодити їх положення між собою шляхом вилучення банкетних та дублюючих норм. Звернуто увагу на те, що потребує уніфікації та законодавчого регулювання: ситуація з визначенням кваліфікаційних вимог до претендентів на посади державної служби в органах судової влади з особливостей посади та обов'язків за цією посадою. Ключові слова: державна служба, судова влада, проходження державної служби, адміністративно-правове регулювання, державний службовець.

В статье исследуется проблема административно-правового регулирования прохождения государственной службы в органах судебной власти. Подробно проанализировано административно-правовое законодательство о государственной службе в органах судебной власти. Предложены пути улучшения административно-правового регулирования государственной службы в органах судебной власти. Автором установлено, что существующее законодательство, регулирующее государственную службу в органах судебной власти, нельзя говорить о том, что оно решает все вопросы государственной службы. В этой статье обосновано, что с целью улучшения нормативно-правового регулирования государственной службы в органах судебной власти необходимо улучшить подзаконное правотворчество в направлении унификации подзаконных правовых актов, согласовать их положение между собой путем изъятия банкетных и дублирующих норм. Обращено внимание, что требует унификации и законодательного регулирования: ситуация с определением квалификационных требований к претендентам на должности государственной службы в органах судебной власти по особенностям должности и обязанностям по этой должности. Ключевые слова: государственная служба, судебная власть, прохождение государственной службы, административно-правовое регулирование, государственный служащий.

The article examines the problem of administrative and legal regulation of civil service in the judiciary. The administrative and legal legislation on civil service in the judiciary is analyzed in detail. Ways to improve the administrative and legal regulation of the civil service in the judiciary are proposed. The author found that the existing legislation governing the civil service in the judiciary cannot be said to address all issues of the civil service. This article substantiates that in order to improve the legal regulation of the civil service in the judiciary it is necessary to improve the law-making in the direction of unification of by-laws, to harmonize their provisions by removing banquet and duplicating rules. Attention is drawn to what needs to be unified and legislated: the situation with the definition of qualification requirements for applicants for civil service positions in the judiciary on the specifics of the position and responsibilities for this position. The article states that in order to improve the legal regulation of the civil service in the judiciary it is necessary to improve bylaws in the direction of unification of bylaws, to harmonize their provisions by removing banquet and duplicating rules; it is necessary to detail all components of civil service in the courts of all levels; to detail and unify the administrative procedures for civil service in category "A" positions; to regulate the list of positions of categories " $B$ " and " $B$ " in the staff of local, appellate courts, higher specialized courts, the staff of the Supreme Court, 
secretariats of the High Council of Justice and the High Qualifications Commission of Judges of Ukraine, the State Judicial Administration of Ukraine, the High Council of Justice; ) The Constitutional Court of Ukraine, the Supreme Court, higher specialized courts, the High Council of Justice, the High Qualification Commission of Judges of Ukraine. Key words: civil service, judiciary, civil service, administrative and legal regulation, civil servant.

Постановка проблеми. В умовах довготривалої судової реформи залишаються невирішеними питання належного забезпечення судової влади високопрофресійним корпусом державних службовців, не заповненими кваліфікованим персоналом залишаються штати апаратів судів, Державної судової адміністрації, Вищої Ради правосуддя, Вищої кваліфікаційної комісії суддів, що зумовлено недоліками адміністративно-правового регулювання всіх етапів проходження державної служби в органах судової влади, відсутністю чітких та прозорих процедур добору на посади державної служби, недосконалістю кадрового планування в системі судової влади, об'єктивних методик оптимального визначення кількісного складу державних службовців в системі органів судової влади залежно від навантаження та функцій і завдань, що виконує конкретний орган судової влади. Незважаючи на важливе значення державної служби в органах судової влади для ефективного здійснення правосуддя, адміністративно-правовий статус державних службовців та особливості їх діяльності наразі законодавчо врегульовані неналежним чином.

Аналіз останніх досліджень і публікацій. Окремі аспекти кадрового забезпечення судової влади досліджували у своїх працях М. Й. Вільгушинський, О.В. Гуцалюк, Я.В.Золотарьова, Р. В. Ігонін, В. В. Ільков, Н. Д. Квасневська, Р. А. Крусян, М. Б. Кравчик, Л. М. Москвич, С. Ю. Обрусна, С.В.Прилуцький, М. І. Смокович, О.В.Ульяновська та ін. Водночас, у вищенаведених наукових працях адміністративно-правове забезпечення державної служби в органах судової влади комплексно не досліджувалося.

Виділення невирішених раніше частин загальної проблеми, котрим присвячується означена стаття. Невисвітленими залишилися питання адміністративно-правового статусу державних службовців органів судової влади, адміністративно-правові процедури проходження державної служби в органах судової влади, стан законодавства у відповідній сфрері, особливості кадрового та організаційного забезпечення державної служби. Зазначені обставини обумовлюють актуальність обраної теми дослідження.

Формулювання цілей статті (постановка завдання). Метою статті $€$ дослідження та висвітлення проблемних питань адміністративноправового регулювання державної служби в органах судової влади.

Виклад основного матеріалу дослідження. Державна служба в органах судової влади в соціальному аспекті представляє собою фрорму віддзеркалення суспільних зв'язків та відносин між державою та особами, які в процесі здійснення своєї професійної діяльності за дорученням держави реалізують завдання та фрункції судової влади. Державна служба в органах судової влади у політичному аспекті $\epsilon$ професійною діяльністю з реалізації державної політики у сфері судоустрою та судочинства, яка виробляється відповідними політичними силами з метою забезпечення функціонування та розвитку судової влади. В організаційному аспекті державна служба в органах судової влади може бути представлена як система органів судової влади, а також організаційно-управлінських норм, способів, правил, стандартів та процедур, що представляють собою єдиний механізм регулювання діяльності осіб, які обіймають в цих органах посади суддів та державної служби. У правовому аспекті державна служба в органах судової влади представляє собою систему юридичних норм, які регулюють функціонування органів управління державною службою та професійну діяльність державних службовців судової влади.

Базовим законодавчим актом, який визначає загальні підстави та порядок проходження державної служби в органах судової влади є Закон України «Про державну службу» від 10.12.2015p. [1]. Дія цього закону поширюється на керівників апаратів (секретаріатів), допоміжних органів, Конституційного Суду України, Верховного Суду, вищих спеціалізованих судів, Вищої ради правосуддя, Вищої кваліфрікаційної комісії суддів України, а також державних колегіальних органів, посади голів та членів яких не належать до посад державної служби.

Наприклад, Закон України «Про Конституційний Суд» регулює порядок призначення на посади керівника Секретаріату Конституційного Суду України, його першого заступника та заступника призначаються на посади та звільняються з посад у порядку, визначеному Законом України «Про Конституційний Суд України». Згідно зі ст. 44 Закону України «Про Конституційний Суд України» керівник Секретаріату має першого заступника, заступників, яких Суд призначає на посаду та звільняє з посади за поданням Голови Суду. Кандидати на посади першого заступника та заступників керівника Секретаріату мають відповідати кваліфрікаційним вимогам, передбаченим Законом України «Про державну службу» для осіб, які претендують на зайняття посади державної служби категорії «А». Тобто ця стаття відсилає до законодавства про державну службу. Тому, можна сказати, що особливості проходження дер- 
жавної служби на вищенаведених посадах все ж регламентуються законодавством про державну службу, крім призначення на посаду керівника секретаріату Конституційного суду. Згідно з ч 3 ст. 44 Закону України «Про Конституційний Суд України». Поряд з цим, Кандидат на посаду керівника Секретаріату повинен мати вищу юридичну освіту та відповідати кваліфікаційним вимогам, передбаченим Законом України «Про державну службу» для осіб, які претендують на зайняття посади державної служби категорії «А» [2].

Державних службовців, інших працівників $\mathrm{Ce}-$ кретаріату призначає на посади та звільняє з посад керівник Секретаріату, крім тих, кого призначає на посаду та звільняє з посади Суд, у порядку, встановленому законодавством про державну службу та про працю [2].

Також, слід зазначити, що згідно з ч. 3 ст. 27 Закону України «Про Вищу раду правосуддя» керівник секретаріату та його заступники призначаються на посади та звільняються з посад Вищою радою правосуддя у порядку, встановленому законодавством про державну службу, з урахуванням особливостей, визначених цим Законом [3]. Однак, у цитованому нами законі ніяких особливостей щодо існуючого порядку призначення на посади керівника секретаріату та його заступників не міститься. Вказана процедура регламентується законодавством про державну службу для осіб, які претендують на зайняття посади державної служби категорії «А».

Закону України «Про державну службу» також встановлює категорії посад держаної служби.

Правовий статус працівників апарату суду визначається Законом України «Про державну службу» з урахуванням особливостей, визначених Законом України «Про судоустрій і статус суддів» від 10.12.2015p. [4]. До цих особливостей відносяться положення ст. 155 Закону про те, що Керівника апарату місцевого суду, його заступника призначає за погодженням голови відповідного суду на посаду та звільняє з посади начальник відповідного територіального управління Державної судової адміністрації України, а керівників апаратів апеляційного суду, вищого спеціалізованого суду, Верховного Суду, їх заступників призначає за погодженням голови відповідного суду на посаду та звільняє з посади Голова Державної судової адміністрації України. Керівник апарату суду призначає на посаду та звільняє з посади працівників апарату суду, застосовує до них заохочення та накладає дисциплінарні стягнення. Добір працівників апарату суду здійснюється на конкурсній основі, крім випадків переведення державних службовців відповідно до законодавства про державну службу.

Особливості перебування на посадах в секретаріаті Вищої ради правосуддя, крім Закону Укра- їни «Про державну службу» регламентує Закон України «Про Вищу раду правосуддя».

Аналіз законодавства дозволив висвітлити такі проблемні питання адміністративно-правового регулювання державної служби в органах судової влади.

Як вже зазначалося вище, у п. 6 ст. 155 Закону України «Про судоустрій і статус суддів» вказано, що правовий статус працівників апарату суду визначається Законом України «Про державну службу» від 10.12.2015p.№ 889 [1]) з урахуванням особливостей, визначених цим законом [4], однак варто зауважити, що конкретизації цих особливостей у заданих вище законах не відбувається. Проблемним моментом є те, що у Законі України «Про державну службу» закріплено категорії посад керівників апаратів суддів, однак неврегульованим залишається питання до категорій яких посад варто віднести державних службовців апаратів судів всіх рівнів, секретаріатів Вищої ради правосудді, Вищої кваліфрікаційної комісії суддів, а також інших державних службовців цих органів. Не міститься у законі прямої вказівки на групи/ підгрупи, до яких потрібно відносити посади державної служби тих чи інших органів судової влади.

Як вже зазначалося вище, у п. 6 ст. 155 Закону України «Про судоустрій і статус суддів» вказано, що правовий статус працівників апарату суду визначається Законом України «Про державну службу» від 10.12.2015p.№ 889) з урахуванням особливостей, визначених цим законом, однак варто зауважити, що конкретизації цих особливостей у заданих вище законах не відбувається. Проблемним моментом є те, що у Законі України «Про державну службу» закріплено категорії посад керівників апаратів суддів, однак неврегульованим залишається питання до категорій яких посад варто віднести державних службовців апаратів судів всіх рівнів, секретаріатів Вищої ради правосудді, Вищої кваліфікаційної комісії суддів, а також інших державних службовців цих органів. Не міститься у законі прямої вказівки на групи/ підгрупи, до яких потрібно відносити посади державної служби тих чи інших органів судової влади. Недоліком законодавства $є$ те, що воно не визначає спеціальні вимоги до посад категорій «Б» та «В» державної служби в органі судової влади.

Висновки 3 цього дослідження. Підсумовуючи вищенаведене слід зазначити, що адміністративно-правове регулювання державної служби в органах судової влади здійснюється нормами спеціального законодавства, яким визначаються види державної служби, особливості її проходження, регламентується адміністративноправовий статус державних службовців. Основні засади державної служби в органах судової влади деталізуються у законодавчих актах, переважно це Закони України «Про судоустрій і статус суддів» 
та «Про державну службу», однак деталізуються у підзаконних правових актах органів судової влади та Національного агентства України з питань державної служби.

3 метою покращення нормативно-правового регулювання державної служби в органах судової влади необхідно покращити підзаконну правотворчість у напрямку уніфрікації підзаконних правових актів, узгодити їх положення між собою шляхом вилучення банкетних та дублюючих норм; слід деталізувати всі складові проходження державної служби в апаратах судів всіх рівнів; деталізувати та уніфрікувати адміністративні процедури про- ходження державної служби на посадах категорії «А»; врегулювати перелік посад категорій «Б» та «В» в апаратах місцевих, апеляційних судів, вищих спеціалізованих судів, апарату Верховного Суду, секретаріатів Вищої ради правосуддя і Вищої кваліфікаційної комісії суддів України, Державної судової адміністрації України, Вищої ради правосуддя, керівників апаратів (секретаріатів) Конституційного Суду України, Верховного Суду, вищих спеціалізованих судів, Вищої ради правосуддя, Вищої кваліфрікаційної комісії суддів України.

\section{БІБЛІОГРАФІЧНИЙ СПИСОК:}

1. Про державну службу: Закон України від 10.12.2015 p URL: https://zakon.rada.gov.ua/laws/show/88919\#Text.

2. Про Конституційний Суд. Закон України від 13.07.2017 URL: https://zakon.rada.gov.ua/laws/show/2136$19 \#$ n2.

3. Про Вищу раду правосуддя : Закон України від 21.12.2016 URL: https://zakon.rada.gov.ua/laws/show/179819\#Text.

4. Про судоустрій і статус суддів. Закон України від 10.12.2015p. URL: https://zakon.rada.gov.ua/laws/ show/1402-19\#Text.

\section{REFERENCES:}

1. Pro dergavnu slugbu. Zakon Ukraini vid 10.12.2015 p. URL: https://zakon.rada.gov.ua/laws/show/889-19\#Text. (in Ukrainian).

2. Pro Konstitutciyniy Sud. Zakon Ukraini vid 13.07.2017 URL: https://zakon.rada.gov.ua/laws/show/2136-19\#n2. (in Ukrainian).

3. Pro Vichu Radu Pravosudiya. Zakon Ukraini vid 21.12.2016 URL: https://zakon.rada.gov.ua/laws/ show/179819\#Text. (in Ukrainian).

4. Pro sudoustriy I status suddiv. Zakon Ukraini vid 10.12.2015p. URL: https://zakon.rada.gov.ua/laws/ show/140219\#Text. (in Ukrainian). 